\title{
Parasitic nematodes of Polychrus acutirostris (Polychrotidae) in the Caatinga biome, Northeastern Brazil
}

\author{
Araujo-Filho, JA. ${ }^{a}$, Ribeiro, SC. ${ }^{b}$, Brito, $S V^{b}$, Teles, DA. ${ }^{c}$, Sousa, JGG. ${ }^{c}$, \\ Ávila, $R W^{a}$ and Almeida, WO. ${ }^{d *}$

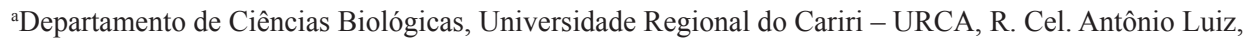 \\ 1161, Pimenta, CEP 63105-000, Crato, CE, Brazil \\ bPrograma de Pós-graduação em Ciências Biológicas (Zoologia), Departamento de Sistemática e Ecologia - DSE, \\ Centro de Ciências Exatas e da Natureza - CCEN, Universidade Federal da Paraíba - UFPB, \\ Cidade Universitária, Campus I, CEP 58059-900, João Pessoa, PB, Brazil \\ 'Programa de Pós-graduação em Bioprospecção Molecular, Universidade Regional do Cariri - URCA, \\ Rua Cel Antônio Luis, 1161, Pimenta, CEP 63100-000, Crato, CE, Brazil \\ ${ }^{\mathrm{d}}$ Departamento de Química Biológica, Universidade Regional do Cariri - URCA, R. Cel. Antônio Luiz, \\ 1161, Pimenta, CEP 63105-000, Crato, CE, Brazil \\ *waltecio@gmail.com
}

Received: March 11, 2013 - Accepted: July 08, 2013 - Distributed: December 31, 2014

\begin{abstract}
We present data on nematode infracommunity of the arboreal lizard Polycrhus acutirostris in the semiarid Caatinga biome, northeastern Brazil. Twenty- twolizard specimens collected in the municipality of Várzea Alegre in Ceará State and in the municipality of Exu in Pernambuco State were analyzed. Two species of nematodes were found, an Oxyuridae, Gynaecometra bahiensis, which had amean intensity of infection $23.5 \pm 5.8$ (prevalence $22 \%$ ) and a Physalopteridae, Physaloptera retusa which had infection intensity of 21 (prevalence 9\%). There were no significant differences between the parasitism rates of male or female lizards. Polychrus acutirostris demonstrated low richness of nematode parasites, but high levels of infection with G. bahiensis. Polychrus acutirostrisis reported here as a new host for P.retusa.
\end{abstract}

Keywords: Polycrhus, parasitism, Nematoda, Gynaecometra bahiensis, Physaloptera retusa, semiarid.

\section{Nematóides parasitas de Polycrhus acutirostris (Polychrotidae) no bioma Caatinga, Nordeste do Brasil}

\section{Resumo}

Apresentamos dados sobre a infracomunidades de nematóides parasitas de Polycrhus acutirostris, lagarto arborícola do bioma Caatinga região semi-árida do nordeste do Brasil. Foram analisados 22 espécimes de lagartos coletados em um ambiente de Caatinga no município de Várzea Alegre, Estado do Ceará e no município de Exu, Pernambuco. Duas espécies de nematóides foram encontradas, um Oxyuridae, Gynaecometra bahiensis, com intensidade média de infecção 23,5 \pm 5,8 (prevalência de 22\%) e um Physalopteridae, Physaloptera retusa, com intensidade de infecção 21 (prevalência de 9\%). Não houve diferenças significativas entre as taxas de parasitismo de lagartos machos ou fêmeas. Polycrhus acutirostris demonstrou baixa riqueza de parasitos, mas altos níveis de infecção por G. bahiensis. Polychrus acutirostris é registrado aqui como um novo hospedeiro para P.retusa.

Palavras-chave: Polycrhus, parasitismo, Nematoda, Gynaecometra bahiensis, Physaloptera retusa, semi-árido.

\section{Introduction}

Helminth communities have been studied in different lizard populations in Brazil, mainly in resting (sandy coastal) (Vrcibradic et al., 2000; Menezes et al., 2004), Cerrado (Brazilian savanna), Pantanal (wetland), and Amazonian biomes (Goldberg et al., 2007; Ávila and Silva, 2010). Recently, our knowledge of lizard parasites in the Caatinga region has been increased by inventories and ecological studies (Anjos et al., 2011; Ávila et al., 2012; Ribeiro et al., 2012a).

Parasitological studies are fundamental to interpreting parasite/host interactions and better understanding related biological communities (Rocha et al., 2003), by indicating 
environmental stress levels, aspects of the ecological web, and elucidating the characteristics of local biodiversity (Marcogliese, 2005).

The arboreal polychrotid lizard Polychrus acutirostris (Spix, 1825) is found in open vegetation formations in Argentina, Bolivia, and Brazil (Garda et al., 2012) in areas of Cerrado and Caatinga vegetation (Kawashita-Ribeiro and Ávila, 2008; Ribeiro et al., 2012b), being often found near human habitations (Vanzolini, 1974). It is a medium-sized diurnal lizard, uses a sit-and-wait foraging strategy and feeds predominantly arthropods (Coleoptera and Hymenoptera), and plant material (leaves, seeds, and flowers), with reproduction between the months of September and October (Vitt and Lacher, 1981). The present study analyzed the parasitic nematodes of $P$. acutirostris in two Caatinga vegetation localities in northeastern Brazil.

\section{Material and Methods}

Specimens of $P$. acutirostris were collected in two areas of Caatinga vegetation, one in the municipality of Várzea Alegre (6 $6^{\circ} 53^{\prime} \mathrm{S}$ and $\left.39^{\circ} 13^{\prime} \mathrm{W}\right)$ in Ceará State, and the other in the municipality of Exu ( $7^{\circ} 33^{\prime} \mathrm{S}$ and $39^{\circ} 44^{\prime} \mathrm{W}$ ) in Pernambuco State. Both sites are located in the semiarid region of northeastern Brazil. The Caatinga vegetation at the Exu site was predominately hypoxerophilous deciduous forest, with average total annual rainfall between 700 and $900 \mathrm{~mm}$ (CPRM, 2005). The Caatinga vegetation at the Várzea Alegre site comprises a mixture of dense shrubs, Cerrado, spiny deciduous forest, and tropical pluvial subdeciduous forest, with an average annual precipitation rate of $965.3 \mathrm{~mm}$, and average annual temperatures between $26^{\circ}$ and $28^{\circ} \mathrm{C}$ (IPECE, 2011).

The lizards were collected by hand between May/2011 in January/2012. They were subsequently euthanized by applying a lethal injection of Lidocaine, weighed using a spring scale (Pesola $\left.{ }^{\circledR}\right)$, and their snout-vent lengths (SVL) measured using a digital caliper $(0.1 \mathrm{~mm}$ precision $)$. The specimens were subsequently fixed in $10 \%$ formaldehyde and conserved in $70 \%$ ethanol. Voucher specimens were deposited in the Coleção Herpetológica da Universidade Regional do Cariri. Individuals were necropsied and their body cavity, lungs and digestive tract were analyzed under a stereoscopic microscope for the presence of helminths. Nematodes encountered were placed in vials of $70 \%$ ethanol for latter identification. For species identification, nematodes were cleared using lactophenol, mounted on temporary slides, and analyzed under a light microscope. The nematodes were subsequently deposited in the Coleção Parasitológica da Universidade Regional do Cariri.

Infection rates as well as ecoparasitological terminology follow the definitions of Bush et al (1997).

We examined the relationships of the host mass ( $g$ ) and snout-vent length (SVL) to the numbers of nematode using Pearson's linear correlation analysis. The differences in infection rates between males and females, as well as differences in their SVL, were examined using the Mann Whitney test (test - U), using Bioestat 5.0 software.

\section{Results}

Twenty-two specimens of Polychrus acutirostris were examined $(\mathrm{SVL}=83 \pm 36 \mathrm{~mm}$; mass $=15 \pm 11 \mathrm{~g})$, from these 11 adult females $(\mathrm{SVL}=100 \pm 16 \mathrm{~mm}$; mass $=22 \pm 11 \mathrm{~g})$, 4 adult males $(\mathrm{SVL}=106 \pm 30 \mathrm{~mm}$; mass $=13 \pm 8 \mathrm{~g})$, and 7 juveniles $(\mathrm{SVL}=43 \pm 32 \mathrm{~mm}$; mass $=5 \pm 1.4 \mathrm{~g})$.

Five individuals (four females $\mathrm{SVL}=108 \pm 5 \mathrm{~mm}$; mass $=32 \pm 4 \mathrm{~g}$; and one male $\mathrm{SVL}=135.8 \mathrm{~mm}$; mass $=24.3 \mathrm{~g}$ ) were parasitized (large intestines) with Gynaecometra bahiensis Araujo, 1976 (Nematoda: Oxyuridae); the mean intensity of infection was $23.5 \pm 5.8$ (prevalence 22\%). One female was parasitized (stomach) with Physaloptera retusa Rudolphi, 1819 (Nematoda: Physalopteridae); the mean intensity of infection with P. retusa was 21 (prevalence 9\%).

The relationship between lizard mass $(\mathrm{g})$ and the number of parasites was significant $\left(\mathrm{r}^{2}=0.85 ; \mathrm{p}=<0.0001\right)$ as well the SVL/parasite relationship $\left(r^{2}=0.5 ; \mathrm{p}=0.0174\right)$. There were no significant relationship between parasite abundance between the sexes (Mann-Whitney, $U=20.50$; $\mathrm{p}=0.67)$; and the variations between male and female sizes (SVL) were likewise not significant (Mann-Whitney, $\mathrm{U}=16.50 ; \mathrm{p}=0.42)$.

\section{Discussion}

Our observations represent the first record of Physaloptera retusa parasitizing Polychrus acutirostris. Nematodes of the family Physalopteridae have been encountered parasitizing representatives of almost all vertebrate classes (Goldberg and Bursey, 1989), and 35 lizard species in Brazil belonging to the families Iguanidae, Polychrotidae, Leiosauridae, Liolaemidae, Tropiduridae, Anguidae, Teiidae, Gymnophthalmidae, and Scincidae have been identified as hosts of P. retusa (Ávila et al., 2012).

Another Caatinga lizard, Tropidurus hispidus Spix 1825, from the states of Ceará and Piauí in northeastern Brazil, was reported to have a prevalence of 33.3\% (Ávila et al., 2012) with $P$. retusa, and the low prevalence found in the present study ( $9 \%$ ) may have been influenced by the number of individuals examined or some aspect of the nematode community analyzed.

Five specimens ( 4 adult females and one adult male) of P. acutirostris had infection with the Oxyuroidea nematode Gynaecometra bahiensis, with high intensity of infection $(23.5 \pm 5.8$; and prevalence of $22 \%)$.

The nematode $G$. bahiensis has only been described as a parasite in P. acutirostris, and additional studies will be necessary to better understand this association (Ávila et al., 2010, 2011). Food habits and foraging modes may influence the composition of host helmintho faunas, and omnivorous and herbivorous lizards are known to have wider and more diverse nematode than carnivorous lizards (Roca, 1999).

Polychrus acutirostris was found to have a low diversity of parasitic nematodes, which could reflect its simple intestinal system, ectothermic metabolism, and/or generalist feeding habits (Goater et al., 1987). 
Little is currently known about the lifecycle of $P$. retusa, although studies with other Physaloptera spp. (such as Physaloptera hispida Petri (1950), Physaloptera maxillaris Molin, 1860, Physaloptera praeputialis von Linstow (1889), and Physaloptera rara Hall and Wigdor, 1918) have shown that infection are initiated by the ingestion of crickets, grasshoppers, and cockroaches contaminated with third stage larvae (Schell, 1952; Lincoln and Anderson, 1975). Polychrus acutirostris is recorded here as a new host for P. retusa. The lifecycle of G. bahiensis has not been well investigated, although other members of Oxyuridae have strictly monoxenic lifecycles (Anderson, 2000). The arboreal habit and omnivorous diet of $P$. acutirostris may have influenced the low number of nematode species infecting this lizard and the high infection intensities encountered.

\section{Acknowledgements}

We are grateful to the Conselho Nacional de Desenvolvimento Científico e Tecnológico - CNPq (PQ-311713/2012-2) for the research grant awarded to W. O. Almeida; the Coordenação de Aperfeiçoamento de Pessoal de Nível Superior - CAPES for the scholarship awarded to S. C. Ribeiro and S. V. Brito; to Instituto Brasileiro do Meio Ambiente e dos Recursos Naturais Renováveis - IBAMA for the collecting permits; to Dr. Roy Richard Funch (UEFS) for suggestions and revision of English version of the manuscript; to M. E. Cabral, D. Q. Dias, D. L. Sales, O. P. Oliveira and F. S. Ferreira for their help with our field work.

\section{References}

ANDERSON, RC., 2000. Nematode parasites of vertebrates: their development and transmission. 2nd ed. Wallingford: CABI Publishing. 650 p. http://dx.doi.org/10.1079/9780851994215.0000.

ANJOS, LA., BEZERRA, CH., PASSOS, DC., ZANCHI, D. and GALDINO, CAB., 2011. Helminth fauna of two gecko lizards, Hemidactylus agrius and Lygodactylus klugei (Gekkonidade) from Caatinga biome, northeastern Brazil. Neotropical Helminthology, vol. 5, no. 2, p. 285-290.

ÁVILA, RW. and SILVA, RJ., 2010. Checklist of helminths from lizards and amphisbaenians (Reptilia, Squamata) of South America. The Journal of Venomous Animals and Toxins including Tropical Diseases, vol. 16, no. 4, p. 543-572. http://dx.doi.org/10.1590/ S1678-91992010000400005.

ÁVILA, RW., SOUZA, FL. and DA SILVA, RJ., 2010. Helminths from seven species of lizards (Reptilia: Squamata) at the Cerrado of Mato Grosso do Sul State, Brazil. Comparative Parasitology, vol. 77, no. 1, p. 67-71. http://dx.doi.org/10.1654/4414.1.

ÁVILA, RW., CARDOSO, MW., ODA, FH. and DA SILVA, RJ., 2011. Helminths from Lizards (Reptilia: Squamata) at the Cerrado of Goiás State, Brazil. Comparative Parasitology, vol. 78, no. 1, p. 120-128. http://dx.doi.org/10.1654/4472.1.

ÁVILA, RW., ANJOS, LA., RIBEIRO, SC., MORAIS, DH., DA SILVA, RJ. and ALMEIDA, WO., 2012. Nematodes of Lizards (Reptilia: Squamata) from Caatinga Biome, Northeastern Brazil.
Comparative Parasitology, vol. 79, no. 1, p. 56-63. http://dx.doi. org/10.1654/4518.1.

BUSH, AO., LAFFERTY, KD., LOTZ, JM. and SHOSTAK, AW., 1997. Parasitology meets ecology on its own terms: Margolis et al. revisited. The Journal of Parasitology, vol. 83, no. 4, p. 575-583. http://dx.doi.org/10.2307/3284227. PMid:9267395

GARDA, AA., COSTA, GC., FRANÇA, FGR., GIUGLIANO, LG., LEITE, GS., MESQUITA, DO., NOGUEIRA, C., TAVARESBASTOS, L., VASCONCELLOS, MM., VIEIRA, GHC., VITT, LJ., WERNECK, FP., WIEDERHECKER, HC. and COLLI, GR., 2012. Reproduction, body size, and diet of Polychrus acutirostris (Squamata: Polychrotidae) in two contrasting environments in Brazil. Journal of Herpetology, vol. 46, no. 1, p. 2-8. http://dx.doi. org/10.1670/10-288.

GOATER, TM., ESCH, GW. and BUSH, AO., 1987. Helminth parasites of sympatric salamanders: ecological concepts at infracommunity, component and compound community levels. American Midland Naturalist, vol. 118, no. 2, p. 289-300. http:// dx.doi.org/10.2307/2425787.

GOLDBERG, SR. and BURSEY, CR., 1989. Physaloptera retusa (Nematoda, Physalopteridae) in naturally infected sagebrush lizards, Sceloporus graciosus (Iguanidae). Journal of Wildlife Diseases, vol. 25, no. 3, p. 425-429. http://dx.doi.org/10.7589/0090-355825.3.425. PMid: 2761018

GOLDBERG, SR., BURSEY, CR., CALDWELL, JP., VITT, LJ. and COSTA, GC., 2007. Gastrointestinal helminths from six species of frogs and three species of lizards, simpratric in Pará State, Brazil. Comparative Parasitology, vol. 74, no. 2, p. 327-342. http://dx.doi.org/10.1654/4268.1

Instituto de Planejamento do Estado do Ceará - IPECE, 2011. Anuário Estatístico do Ceará: perfil básico dos municípios. Available from: <www.ipece.ce.gov.br>. Access in: 15 Mar. 2012.

KAWASHITA-RIBEIRO, RA. and ÁVILA, RW., 2008. Reptilia,Squamata, Polychrus spp.: new record, range extensions, and distribution map in the State of MatoGrosso, Brazil. Check List, vol. 4, no. 3, p. 362-365.

LINCOLN, RC. and ANDERSON, RC., 1975. Development of Physaloptera maxillaris (Nematodea) in the common field cricket (Gryllus pennsylvanicus). Canadian Journal of Zoology, vol. 53, no. 4, p. 385-390. http://dx.doi.org/10.1139/z75-051.

MARCOGLIESE, DJ., 2005. Parasites of the superorganism: are they indicators of ecosystem health? International Journal for Parasitology, vol. 35, no. 7, p. 705-716. http://dx.doi.org/10.1016/j. ijpara.2005.01.015. PMid:15925594

MENEZES, VA., VRCIBRADIC, D., VICENTE, JJ., DUTRA, GF. and ROCHA, CF., 2004. Helminths infecting the parthenogenetic whiptail lizard Cnemidophorus nativo in a restinga habitat of Bahia State, Brazil. Journal of Helminthology, vol. 78, no. 4, p. 323-328. http://dx.doi.org/10.1079/JOH2004247. PMid:15575989

RIBEIRO, SC., FERREIRA, FS., BRITO, SV., TELES, DA., ÁVILA, RW., ALMEIDA, WO., ANJOS, LA. and GUARNIERI, MC., 2012a. Pulmonary infection in two sympatric lizards, Mabuya arajara (Scincidae) and Anolis brasiliensis (Polychrotidae) from a cloud forest in Chapada do Araripe, Ceará, Northeastern Brazil. Revista Brasileira de Biologia = Brazilian Journal of Biology, vol. 72, no. 4, p. 929-933. http://dx.doi.org/10.1590/S151969842012000500021. PMid:23295524

RIBEIRO, SC., ROBERTO, IJ., SALES, DL., ÁVILA, RW. and ALMEIDA, WO., 2012b. Amphibians and reptiles from the 
Araripe bioregion, northeastern Brazil. Salamandra (Frankfurt), vol. 48, no. 4, p. 133-146.

ROCA, V., 1999. Relación entre la faunas endoparasitas de reptiles y su tipo de alimentacíon. Revista Española de Herpetologia, vol. 13 , p. 10-21.

ROCHA, CFD., VRCIBRADIC, D., VICENTE, JJ. and CUNHABARROS, M., 2003. Helminths infecting Mabuya dorsivittata (Lacertilia, Scincidae) from a high-altitude habitat in Itatiaia National Park, Rio de Janeiro State, southeastern Brazil. Revista Brasileira de Biologia = Brazilian Journal of Biology, vol. 63, no. 1, p. 129-132. http://dx.doi.org/10.1590/S1519-69842003000100017. PMid:12914424

SCHELL, SC., 1952. Studies on the life cycle of Physaloptera hispida Schell (Nematoda:Spiruroidea) a parasite of the cotton rat (Sigmodon hispidus littoralis Chapman). The Journal of Parasitology, vol. 38, no. 5, p. 462-472. http://dx.doi.org/10.2307/3273926. PMid:12991140
Serviço Geológico do Brasil - CPRM, 2005. Projeto cadastro de fontes de abastecimento por água subterrânea: diagnóstico do município de Exu, estado de Pernambuco. Recife: CPRM/ PRODEEM. Available from: $<$ http://www.cprm.gov.br/>. Access in: 20 Mar. 2012.

VANZOLINI, PE., 1974. Ecological and geographical distribution of lizards in Pernambuco, northeastern Brazil. Papéis Avulsos de Zoologia, vol. 25, no. 4, p. 61-90.

VITT, LJ. and LACHER, TE., 1981. Behavior, habitat, diet and reproduction of the iguanid lizard Polychrus acutirostris in the Caatinga of Northeastern Brazil. Herpetologica, vol. 37, no. 1, p. 53-63.

VRCIBRADIC, D., CUNHA-BARROS, M., VICENTE, JJ., CONRADO, ACG., HATANO, FH., SLUYS, MV. and ROCHA, CFD., 2000. Nematode infection patterns in four sympatric lizards from a restinga habitat (Jurubatiba) in Rio de Janeiro state, southeastern Brazil. Amphibia-Reptilia, vol. 21, no. 3, p. 307-316. http://dx.doi.org/10.1163/156853800507507. 